\title{
Network governance and capacity of local governments to deliver LED in Uganda
}

\section{Commonwealth Journal of Local Governance \\ Issue 18: December 2015 \\ http://epress.lib.uts.edu.au/ojs/index.php/cjlg}

\author{
Rose B Namara
}

Uganda Management Institute

Uganda

\section{Gerald Kagambirwe Karyeija}

Uganda Management Institute

Uganda

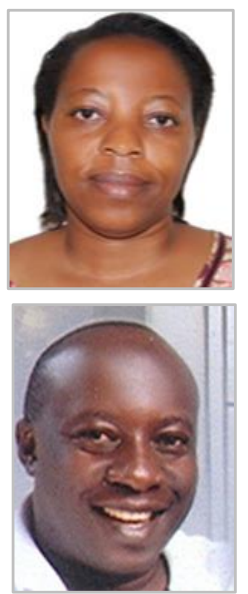

\section{Betty C Mubangizi}

School of Management, IT and Governance

University of KwaZulu Natal

South Africa

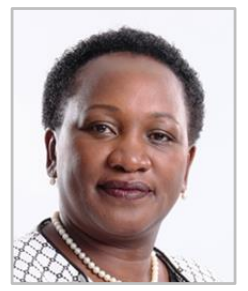

\begin{abstract}
This paper discusses network governance and its contribution to the capacity of local governments (LGs) to deliver local economic development (LED) in Uganda. Although a formal LED policy was only established in Uganda in February 2014, there have been LED-inspired practices in the past decade. Various scholars and practitioners have observed that the autonomy and capacity of LGs to deliver LED is limited, but have been hopeful that new governance strategies like network governance would increase the capacities of LGs. However, neither network governance arrangements among LGs, nor their potential to improve governance capacity, have been documented. In a case study of Kyenjojo District, this paper finds that existing network governance arrangements have been fundamental in improving financial autonomy at this $L G$, delivering some income to invest in LED activities, although no evidence was found of reduced transaction costs in transforming local economies. The study further reveals that network governance arrangements have not led to the development of specialised skills in regulation or law enforcement, and capacity gaps are evident amongst staff and members in understanding the private sector and how it works. On a positive note, there is clear evidence of attempts by the LG to be innovative. Based on these findings, this study recommends that LGs need to consider a multi-pronged or multi-network governance approach to $L E D$, which in turn will require a refocusing of governance mechanisms to become more dynamic and responsive, and offer incentives to the various actors in the development sector.
\end{abstract}

Keywords: Network governance, local government capacity, local economic development, Uganda

(C) 2015 Rose B Namara, Gerald Kagambirwe Karyeija and Betty C Mubangizi. This is an Open Access article distributed under the terms of the Creative Commons Attribution 4.0 Unported (CC BY 4.0) License (https://creativecommons.org/licenses/by/4.0 (https://creativecommons.org/licenses/by/4.0/), allowing third parties to copy and redistribute the material in any medium or format and to remix, transform, and build upon the material for any purpose, even commercially, provided the original work is properly cited and states its license. 


\section{Introduction}

Within a decentralised governance framework, local economic development (LED) is perceived as the responsibility of local governments (LGs). For example, at the Kampala Commonwealth Local Government Conference in 2013, LGs were declared to be central to the development process, with a role to promote:

- local democratic governance that is inclusive, transparent and participatory;

- democratic development and public participation;

- innovative, sustainable, people-sensitive local economic growth and social development;

- integration and coordination of development activities between public and non-state agents;

- human rights, gender equality, cultural diversity and non- discrimination;

- the building of social capital, peace and stability, and dialogue (CLGF 2013, p. 21).

LGs are thus seen as catalysts and accelerators of LED. According to Rogerson (2010, p. 485) they have: a political role in democratically determining what is suitable for their localities; social responsibility for ensuring local development is inclusive and fair; and a responsibility to ensure that public, private and community actors in LED are coordinated and their interests are met. Similarly, the International Labour Organization (2006, p. 2) sees LED as a participatory process that encourages partnership arrangements between the private and public stakeholders of a defined territory, enabling joint design and implementation of a common development strategy by making use of local resources and competitive advantage in a global context, with the final objective of creating decent jobs and stimulating economic activity.

In Africa, the persistent challenges facing decentralisation and local governance have necessitated a refocusing of LED efforts. These challenges include: inadequate local revenues and business development support; an unfavourable business environment; inadequate management information systems, and insufficiently business-like approaches to service delivery (Huntington and Wibbels 2014, p. 632; Rees and Hossain 2010, p. 584). It is envisaged that LED will "encourage and support networking and collaboration between businesses and public and private and community partnerships, facilitate workforce development and education, focus inward investment to support cluster growth and support quality of life improvements" (Ruecker and Trah 2007, p. 13). Thus LED is understood as being generated by the efforts of many actors.

According to new public management (NPM) theory, many actors contribute to the achievement of governance objectives, but these must find ways to interact that increase effectiveness in implementing policies and programmes (Mubangizi et al. 2013). This interaction highlights both intra- and inter-relational issues. In the case of intergovernmental relations, the relationship between 
local and central government is broadly defined by legislation, but needs facilitating initiatives to work effectively.

There is also growing scrutiny of how the private sector and other actors, relate to LGs. The private sector is seen to be critical to local development since it tends to drive growth. In Uganda, for instance, the private sector contributes about $80 \%$ of economic growth (Read and Parton 2009, p. 579), particularly small and medium-sized enterprises such as smallholder farms, retail and agroprocessing businesses, and providers of health, education and financial services. A strong local private sector and/or strong economic growth in a country can then attract foreign investment (Choong and Lam 2010, p. 184). For this reason governments are devising new governance approaches, such as network governance and public-private partnerships, to include other players in delivering public services. These horizontal relationships, and public/private/community coordination, are increasingly the subject of academic focus.

Network governance (cooperation between government agencies) and collaborative governance (cooperation with external agencies e.g. through public-private partnerships) are being encouraged as examples of innovative public sector management (Park and Park 2009, p. 92). The idea of a 'network' implies interaction between various actors on the basis of trust, with the aim of solving a policy problem, rather than relying on systems of operation.

Network governance can create a sense of collective action and mutual support, to harness the network of resources more efficiently and effectively. Network governance is expected to transform local governance by stimulating the local economy to grow, compete and create jobs, and make better use of local resources (Trah 2004). Network governance can improve inter- and intra-government relationships as it enhances team spirit, mutual accountability and coordination. For instance, Mubangizi et al. (2013) conclude that the successful implementation of the KwaNaLoGA Games and the Uganda Nutritional and Early Childhood Development Programme are two good examples of coordination, communication and relationships within a network of actors.

Mubangizi et al. further note that network governance has inherent capacity-building and knowledge exchange benefits. Actors can adapt and innovate, exchange ideas or even increase the numbers of skilled personnel to undertake an activity (although this paper does not look at specific sectors). Network governance thus departs from debates on governance, e.g. local governance, multi-level governance or 'good governance', by considering (1) patterns of interaction in exchange and relationships; and (2) flows of resources between independent units (Wilikilagi 2009).

For example in LED, Koppenjan and Klijn (2004) claim that common policy problems faced by local governments can be addressed by network coordination of resources, skills and strategies. In contrast, 
de Vries and Nemec $(2012$, p. 4) state that focusing on whole-government issues and horizontal coordination have affected the autonomy of public organisations, though they do not elaborate how.

However, the more the interaction is brokered, the more centralised it appears. Awortwi (2003) shows that, during partnerships in service delivery, agents - in this case civil society organisations and private companies - innovate to save costs, and thus develop capacity for future sub-contracting and increase their entrepreneurial confidence; at the same time, the image of local government improves. Awortwi (2003) emphasised the range of skills that LGs need to improve governance of multiple forms of service delivery, e.g. equipping staff with skills to manage contracts, monitoring progress indicators, implement by-laws and sanctions, and improve negotiation skills so as to achieve better terms and build consensus.

This paper, therefore, asks the following question: does network governance contribute to the capacity of LGs to deliver local economic development? More specifically:

1. Does network governance contribute to the financial autonomy of LGs?

2. Does network governance contribute to the functional/human capacity of LGs?

3. Does network governance increase innovation and recognition of local opportunities by LGs?

\section{Local economic development strategies}

In order to address the above questions, a clear understanding of local economic development (LED) strategies is needed, especially as they are understood and used in this study. This section therefore seeks to provide a discussion and explanation of LED.

LED is "a process of stimulating the local economy to grow, compete and create more jobs, in particular making better use of locally available resources" (Trah 2004, cited in Rogerson and Rogerson 2010). This process is driven by all sectors in development, and the Government of Uganda defines LED as "a process where the tripartite partnership between local governments, private sector and community are jointly and collectively engaged in identification, mobilisation, management and initiation of resources at the local levels" (MoLG 2013). LED is commonly characterised by the following attributes: participation and social dialogue; territorial focus; mobilisation and use of local resources; building of competitive advantage; local ownership and management; and multiple stakeholder involvement (MoLG 2013; MoLG 2014). Ateljevic et al. (2013, p. 282) emphasise that it is about building the economic capacity of a local area to improve its economic future and the quality of life for all. It is a process by which the public, business and NGO sectors work collectively to create better conditions for employment generation. LED performance and sustainability depend on the active engagement of the private, public and third sectors, and of communities. 
Often LED appears fragmented, featuring autonomous individuals, agencies and institutions whose relationships are characterised by uncoordinated service delivery, unclear jurisdiction, and some manipulation. However, LED also brings together many different types of enterprises, such as shops, market stalls, hotels, agribusinesses, property companies, shopping malls, leisure parks and food processing plants. Tourism sites, for example, may be started, operated and maintained by individuals or private companies, who may own, rent, or lease such enterprises. Not all enterprises are known to, or registered with, local authorities.

NGOs contributing to LED operate in different ways in different localities, and may not declare their work plans and budgets to LGs. Thus their budgets are not usually reflected in district plans, nor are they taxed, making it difficult to gauge their contribution to LED. Where NGOs support the budgets of LGs, either in cash or kind (e.g. vehicles, computers, construction of health centres or schools, their contribution to local economies is more easily tracked. This fragmentation, in which different actors have different agendas, makes governance, planning, monitoring, control and evaluation of LED difficult. Appropriate governance and oversight is thus urgently needed.

Mubangizi et al. (2013, p. 777) conclude that "in a decentralized system, network governance can indeed contribute to service delivery amidst resource-poor units of $L G$, especially if there is strong and effective collaboration across the different spheres of government, private sector and civil society". Several scholars (eg Bogason and Musso 2006) agree that network governance is a useful local and, as development becomes more complex, and government depends more on other actors to solve problems, network governance offers an overarching strategy for facilitating ordered and collective action (Giest and Howlett 2013). The need for coordinated effort among interdependent entities, for collective solutions to public issues, and for recognition of the importance of a range of actors in development, is at the heart of network and collective governance. As a result, governments are employing "looser forms of governance where private actors such as business and NGOs increasingly participate in policy-making" (Khan 2013, p. 134) - such actors are thus involved in policy implementation, unlike governance by hierarchical structures (where rule is based on rigidly structured command structures) or markets (based on demand and supply) (Khan 2013; Parag et al. 2013).

Turnbull (2007) and Khan (2013) list some useful distinguishing characteristics of network governance and their relevance to LED processes. Turnbull (2007) emphasises that in networks actors are interdependent, they cooperate with and trust each other, and most importantly stakeholders work in an organised manner towards a common solution. 
This process is explained below:

- The network comprises autonomous organisations with interdependent centres of power. This division of power can be used to introduce checks and balances in a network, although networks have been criticised for maintaining power imbalances (Khan 2013).

- There is proper coordination and communication among players, i.e. "politically independent feedback and feed-forward communication and control channels" (Turnbull 2007, p. 1080). This can create competition for both information and power and improve performance.

- Stakeholders affected by a problem - for example employees, customers and suppliers participate in its resolution. This provides a check on excessive bureaucratic powers. At the same time, networks typically include 'gatekeeper', 'pulse-taker' and 'innovator' roles, whose presence stimulates action and sharing of skills and resources.

Thus network governance "introduces distributed communications, intelligence, decision- making and control, which reduce centralized powers and promote democracy" (Turnbull 2007, p. 1080) and increases connectivity. Network governance also facilitates access to essential information and resources; increases the influence of actors; increases access to resources; and reduces transaction costs. Networking can also help solve complex problems by allowing exchange of capabilities and markets, and by combining different types of knowledge (Parag et al. 2013; Giest and Howlett 2013).

Network governance happens within both formal and informal arrangements. Khan notes (2013, p. 134) that network governance covers a broad range of organisational forms from public-private partnerships and stakeholder participation to informal personal interactions between individuals. These interactions and organisational arrangements are dictated by "various motives for joining the network and differing opinions on the preferred outcome" (Green, 2003).

Incentives are also needed to promote cooperation (Provan and Kenis 2008; Giest and Howlett 2013). For some actors the incentive may be a situation that is too complex for them to handle - as evidenced by Bodolica and Spraggon (2009, p. 114), who suggest that failing businesses may seek mergers and collaborations to survive or grow, although such collaboration may be ad hoc and unsustainable. Other incentives may come when government provides a funding inducement or opportunity which persuades other actors to cooperate. For example, in Uganda, the Presidential Initiative Fund offers funding to local entrepreneurs who devise value-adding innovations. Sometimes, governments may introduce incentives as sanctions - e.g. a tax to increase costs for firms which do not collaborate in a programme. However, for network governance to succeed trust is a core element (Park and Park 2009, p. 103). 
Based on cluster network analysis of LED in 2,904 municipalities in the United States, Reese (2006) found three major development approaches adopted by cities to develop their localities:

a) combining infrastructure investment and financial incentives;

b) using all possible techniques (e.g. tax holidays, marketing, land-based incentives, business assistance etc); and

c) a passive strategy in which little is done (which the author found in 210 cities).

Reese concludes that the lack of clear strategies for LED in cities calls into question not only how far local government is seen as the driver of LED, but also the capacity of local governments to pursue LED. Although the present paper does not question the primacy of LGs to spearhead LED, it does explore whether network governance affects the capacity of LGs to deliver LED.

Awortwi (2003) has studied public-private partnerships in their role as one of the planned network governance arrangements often chosen for the delivery of public services. Public-private partnerships constitute a contractual arrangement between LGs and agents (private actors) involving transfer of responsibilities, opportunities and risks (capital, ownership and management). Awortwi showed that public-private partnership contracts can operate within a range of governance structures, namely:

- Contracting-out: the LG hires an agent to carry out specified tasks for a period of time. The LG pays for service delivery, sets performance expectations, clarifies delivery parameters, and monitors and deals with the service provider directly. The LG has a limited relationship with service users.

- Franchising: the LG gives exclusive rights or a geographical monopoly to a private firm to deliver services to and collect fees directly from beneficiaries, while the LG taxes the firm through surcharges.

- Open competition: the LG allows registered firms to make private arrangements with users to deliver a service. The firms compete for clients in the market. The role of the LG is to license, monitor and regulate the firms.

- Leasing: private operators rent the assets of an LG to deliver a service for a certain period of time. The private operator assumes all commercial risks involved in operating, maintaining and managing the asset, and pays a rental fee to the LG.

- Granting of concessions: the LG gives a private company full responsibility for delivery of specified infrastructure services. The private company is responsible for capital development required to build, upgrade or expand the system. Users pay tariffs and the LG is responsible for establishing performance standards and ensuring that the concessionaire meets them. In some cases, the concessionaire may maintain indefinite ownership (the 'build, operate and own' model), while in others the assets may be transferred to the LG after a period of time. 
However, Awortwi noted that whichever type of governance through contracting is chosen, the LG needs the capacity to contract well and efficiently, or public trust and confidence in the government itself may be undermined. Creating 'smarter' LGs remains a very critical requirement for achieving a meaningful LED strategy for Uganda.

\section{Capacity of local governments to offer LED}

There is no doubt that building local economies' capacity to create wealth and wellbeing for local residents requires functional capacity from both private and public actors. President Kagame of Rwanda summed it up well when he said: "We believe that effective decentralization does not only require the autonomy of $L G$ institutions, but most importantly the requisite capacities to deliver on their mandate, as well as continued support from, and coordination with, the central government" (Kagame 2013, p. 13). In a decentralised setting LGs are supposedly in charge, autonomous and capable of promoting growth and development within their localities. An effective LG needs to have both the autonomy and ability to coordinate - horizontally or vertically - other players in meeting local priorities, and the insight to identify and exploit local opportunities to expand the local economy. LGs can steer development if they seize these local opportunities and encourage community participation (CLGF 2013). Therefore 'capacity' for LGs includes autonomy to operate; a mandate to regulate, plan, implement or facilitate service delivery; and powers and skills to monitor LED interventions.

\section{Autonomy of LGs}

The autonomy of LGs as key actors in LED is important because it determines how they become entitled to participate in networks, the role they play in defining public interest, whether they take a leadership or 'led' role, their place with regard to funding, and whose interests they represent. From a political economy perspective, autonomy in public administration and governance defines jurisdiction, the power of local actors, dominance, legitimacy and discretionary authority (Swianiewicz 2014, p. 293). Legislative frameworks that promote decentralisation recognise LGs as autonomous and powerful institutions in local economies. However, when actors like NGOs become involved in provision of public services, to supplement government efforts, they become more powerful at local levels and their role goes beyond mere service provision. For instance, they are able to determine the absence or presence of a service, and this "has implications for the degree to which local government maintains its control over service provision and the accountability of providers to citizens and their elected representatives" (Bar-Nir and Gal 2010). In such situations it is crucial to clarify the roles and responsibilities of both NGOs and LGs, as LGs may otherwise be perceived to have made decisions affecting the wellbeing of citizens in ways that are contentious, when in fact 
their actions may not be completely autonomous (Hansen and Klausen 2002, p. 49; Grant and Dollery 2012, p. 401).

Previous work on the autonomy of LGs (eg Jones and Stewart 2012) has mainly focused on the relationship with central government. Such studies have claimed that LGs are not truly autonomous because they are controlled by central government, which funds most activities, sets policies and determines structures of operation. Jones and Stewart claim that failure by LGs is often embedded in central government systems, e.g. when allocated funding that propels and sustains localism is not provided. LGs are seen simply as extensions of central governments and conduits of funding to civil society organisations which implement local public services. A recent study by Palermo (2015, p. 246) focuses on four variables to understand the autonomy of LGs: function, structure, administration and finance. One of its conclusions is that structure and administration are largely dictated by legal provisions, meaning that governance models like network governance cannot significantly influence these variables. This seems to be borne out in Uganda, where recently a number of functions structure, administration and even finance - have been re-centralised (Lewis 2014, p. 584; Karyeija and Kyohairwe 2012; Nabukeera et al. 2015). It is clear there are a number of empirical convergences between the Italian and Ugandan experiences, though they may differ in degree of and motive for recentralisation. This paper focuses on the effect of network governance on the financial, functional and innovative autonomy of local governments.

\section{Financial autonomy}

Imhanlahimi and Ikeanyibe (2009) found LG autonomy in Nigeria was weak, characterised by inadequate finances, weak intergovernmental relations, precarious democracy and corruption on a grand scale. Similarly Kiwanuka (2014) maintains that LG autonomy is very difficult to achieve without a sound local revenue base and an efficient tax collection system. In Uganda, although LGs do have powers to raise funds from services such as property rates, land, licences etc, or to set their own rates and enact laws to reduce tax evasion, there is still limited participation of the private sector in planned LED, businesses are largely informal and the capacity of local economies to provide infrastructure to spur LED is inadequate (MoLG 2013). There is no doubt that lack of financial autonomy may constrain LGs from implementing development initiatives. However, literature on network governance does not document how different network arrangements enable LGs to increase their capacity to generate and spend their own income on LED priorities; although there are clearly capacity gaps in supporting the development activities implemented by private actors.

In a discussion about LGs' capacity to support other actors under LG jurisdiction, Awortwi (2003, p. 260) investigated examples of governance of basic service delivery in Ghana. He concluded that LG bureaucrats did not have suitable systems to facilitate and incorporate even the activities of 
community-based organisations (CBOs) in their budgets and financial allocations. He noted that bureaucrats even asked for monetary incentives such as sitting allowances in order to attend $\mathrm{CBO}$ meetings - which undermines the idea of cooperation and networking. In joint undertakings, he found that LGs did not honour their financial obligations over development interventions, even when these were handed over to them. In the case of a joint sewage scheme in Ghana, Awortwi (2003, p. 260) noted it was abandoned a few months after inauguration. He concluded that LGs had not yet taken conscious and consistent steps to enable CBOs to access financial resources, or to harness stakeholder participation.

Turning to Uganda, are LGs here able to honour their financial obligations to networks? The Ministry of Local Government in Uganda (MoLG 2014) conducted a review of district development plans in Uganda and concluded that there was 'a weak focus to private sector development' but that there existed more detailed plans, programmes, targets and monitoring arrangements for public sector performance. There were no specific plans for developing partnerships with the private sector. Limited attention and resources are focused on private sector development by LGs - and yet the private sector is an engine of LED. Strategies need to be available to LGs in Uganda to engage private actors in LED, as well as to increase the financial autonomy of local governments.

\section{Functional capacity}

It is worth investigating whether LGs actually have the functional capacity to discharge their mandates to regulate, plan, implement or facilitate implementers, and monitor network governance. LGs need to be able to effectively manage different modes of partnership in service delivery (Awortwi 2003). One critical capacity is the ability to regulate agents: paying them when services are delivered and monitoring and sanctioning them if they are at fault. Awortwi emphasised that in cases where, for example, social services are implemented under commercial or market-oriented principles, LGs have to reorganise to manage two key risks: the risk of poor service delivery, and the risk of noncompliance with LG regulations. Only if these risks are successfully managed will they obtain substantial gains from the partnership, such as increased coverage and greater efficiency in service delivery. Additionally, although 'reorganisation' is often synonymous with 'restructuring' in organisational development literature, this paper argues that what is needed here is the reorientation of LG capabilities and development of skills. Necessary skills for LGs will include contract management, monitoring and evaluation. However, Awortwi concluded that none of the LGs he studied had the capacity to govern such partnerships sufficiently to ensure value for money. $\mathrm{He}$ attributed this poor performance to poor decentralisation policies and inadequate fiscal, human and political autonomy among LGs. 
In this paper functional capacity is analysed by looking at human resources capacity to undertake LED using looser forms of governance.

Bayar and Mayer (1994, pp. 153-154), cited in Tshikwatamba (2012), over 20 years ago argued for a paradigm shift of governance towards expertise, power-sharing, two-way information flows, and collective leadership and management styles. They argued that this paradigm shift demands a reorientation of capacities. This orientation is important because in earlier models of governance governments employed people to deliver services, but not to manage contracts. Redman et al. (2007, p. 1489) note a shift in the human resource needs of government from a supply perspective to a demand and/or needs-driven perspective. This demand-driven side requires specialised regulation, facilitation and monitoring skills, and the ability to balance vertical and horizontal interactions.

In addition to technical abilities, network leaders must be able to balance horizontal and vertical relationships in such a way as to create trust and reciprocity within the network. They must communicate well, persuade stakeholders to continuously interact and exchange knowledge, and direct network management activities. Cristofoli et al. (2014) insist that for networks to successfully perform they "must be able to rely on formalised mechanisms and a pool of 'network administrators' responsible for their governance". Giest and Howlett (2013) argue that good network leaders can attract new members to the network, build long-term networking structures and also attract funding opportunities. Does network governance facilitate the growth of such human capacity in LGs in Uganda?

\section{Innovative capacity of LGs}

Long-term changes in localities require managers of LGs to come up with innovative ideas. Grydehøj (2013) argues that innovative governance practices can promote economic development in LGs, to an extent, nurturing a small jurisdiction's core competencies and making government policy more effective (Grydehøj 2013). Using the example of Shetland, UK (a sub-national jurisdiction in the EU), Grydehøj shows how the creation of a parallel structure to a local government, the Shetland Charitable Trust, gave more autonomy and capacity to LGs to manage their local economy. Upon the discovery of new oil resources, Shetland Council created the Trust to manage the oil reserve fund. The Trust managed taxes and contracts with oil companies, and had authority to offer grants and credit to Shetland inhabitants. Although the Trust managed an LG fund, it did not mirror LG structures. The fund grew in size and boosted businesses in Shetland. Innovative governance in an LG may be constrained by central government regulations, because politicians are not always eager to empower LGs, but the Shetland experience indicates that a strong sense of identity and support from citizens may make innovations at LG level work. One of the major reasons for the emergence of networks has been to find innovative solutions to complex policy problems that are commonly 
experienced and which cannot be solved by a single actor. Nonetheless, concern remains as to how network governance can enable LGs to be innovative (ie to develop and implement ideas).

In the sections that follow, this paper documents a case study of how and to what extent network governance affects the capacity of an LG in Uganda - namely Kyenjojo District. First, it examines the network arrangements promoting LED in Kyenjojo. Second, it explains the methodology used for this study. Third, the major findings are presented and analysed. Lastly the findings are discussed and conclusions are drawn.

\section{LED in Uganda}

Uganda's national economy has been growing stronger, with an impressive growth rate of $6.7 \%$ in the financial year 2010/11, against 5.9\% in previous years (MoLG 2014). This growth is mainly attributed to the mining, construction and telecommunications sectors, and to heavy investment in infrastructure development - including roads, water and sanitation, air and railways, energy and information technology. The government has invested in national 'backbone' data transmission infrastructure and e-government infrastructure to encourage e-governance, e-marketing and e-procurement. Mobile phone technology has encouraged the growth of businesses such as mobile money transfer kiosks. The liberalisation of radio and TV broadcasting has increased information-sharing and the participation of citizens in local development. Rural electrification has aided the growth of rural businesses, while investment in the rural road network has facilitated trade, marketing and the transfer of perishables such as flowers and vegetables to market.

Decentralisation and the creation of many LG units has seen some commendable successes such as stabilising local governance by widening involvement, encouraging citizen participation in local decision-making, and improving service delivery to a degree. However, there have also been challenges, such as: inadequate local revenues (averaging just 3\% of total local government annual budgets); unhelpful business practices such as long registration procedures; inadequate business development services; an insufficiently business-like approach to service delivery by bureaucrats; the informal nature of most businesses; and procurement laws that sometimes hamper effective publicprivate partnerships (MoLG 2014).

Recognition that the private sector in recent years is a key mover of the Ugandan economy has resulted in 20\% annual growth of this sector (MoLG 2014), and in fact the sector has seen steady average annual growth of 5.5\% over the last 15 years (2000/01 to 2014/15) (Ministry of Finance, Planning and Economic Development 2015, p. 3). The sector is dominated by micro enterprises, but also includes agro-processing (fruit, juice), eco-tourism, mining and locally-based small businesses. The continued growth of a vibrant private sector is envisaged right across the Ugandan economy and 
is expected to boost LED through the trickle-down effect. However, the private sector still faces several challenges, including: limited access to financial services; limited financial literacy; the high cost of doing business; the poor quality of local products, which prevents them from competing favourably; inadequate investment in research; and generally a limited focus on the private sector by LGs. This is seen in a recent review of LGs' development plans, which found that there are no specific plans for developing partnerships with the private sector, since plans are geared towards meeting constituents' demands (MoLG 2013). Local-level private sector lobby groups are also weak or non-existent in Uganda.

LED, particularly the development of an effective private sector, requires policies and plans that can balance both private and public interests. Documented cases of such public-private partnerships do exist in Uganda. For instance, Entebbe town through a public-private partnership has built a leisure park which generates income not only for the owners but also for local communities, by providing employment and a market for their produce. It also helps the LG beautify the town, and protects the environment through tree-planting and waste management. In Jinja town, the LG joined with local business owners to paint buildings, refurbish and improve dilapidated streets, develop open spaces for recreation, and improve public sanitation, street lighting and roads. In 'City Bright' campaigns, communities work alongside LGs to beautify their cities (CLGF 2013). However, the participation and collaboration of actors in LED is governed by both positive and negative incentives embedded in policies, plans and practices. Although Uganda's LED strategy was adopted by all LG leaders during their joint annual review of decentralisation in 2007 (Bitarabeho 2008, p. 6), Uganda did not have a national LED policy until February 2014. Significantly, this policy, together with Uganda's Decentralisation Policy Strategic Framework (2013-2023), provides a framework for partnerships and aims to accelerate and galvanise social and economic actors to effectively address LED.

\section{Network governance arrangements promoting LED in Kyenjojo District}

The current structure of LGs in Uganda is comparatively favourable to both horizontal and vertical coordination of local priorities. Network governance strategies offer scope to build the capabilities of LGs, private sector institutions and communities to sustain many viable initiatives. Kyenjojo District does not have a specific LED strategy, but manages to implement strategies which broadly fit within the Ugandan national policy on LED of 2014. Kyenjojo District was selected for this study because it is a typical rural LG with a mix of small and large private companies and NGOs operating in the area, so it was felt that an analysis of its network governance would be informative in a wider context.

Kyenjojo District is located in western Uganda. It is bordered by Kibale District to the north, Kyegegwa District to the east, Kamwenge District to the south and Kabarole District to the west. The 
district headquarters are approximately $274 \mathrm{~km}$ from Kampala City by road. Like all LGs, Kyenjojo is mandated to provide services for local citizens and promote LED.

\section{Methodology}

This study uses an exploratory case study design to explore, describe and explain the connection between how localised network governance is implemented and how localities are transformed in Uganda. Qualitative interviews were conducted with both Kyenjojo LG officials (district planning, human resources, finance, and community development departments) and local business owners (shopkeepers, roadside stall owners, market stall owners, hotel managers and officials from tea companies). Businesses chosen had all operated in the district for at least five years, meaning they had significant experience of working with LG officials, and had witnessed changes in the local economy. A total of 30 respondents, selected purposively and for convenience, participated in the interviews.

Information was collected on: the nature of cooperation and coordination; the kind of issues on which the LG engaged local businesses; LG actors and their approach to network governance; the capacities of LG staff; and the effects network governance had on LGs' autonomy and innovation in their delivery of LED. As the data was qualitative rather than quantitative, thematic analysis was used to identify patterns and understand the key findings. The data is presented in the voices of the participants, followed by analysis by the authors.

\section{Findings}

Three major strategies (infrastructure development, contracting out, and taxation) were identified within which to analyse the financial autonomy, human resources capacity, and innovative abilities of the LG.

\section{Infrastructure development}

This strategy included construction of roads and health centres, and encouragement to the banking sector to open branches or offer mobile banking services. Kyenjojo LG has approached work on roads in two ways: a) a joint undertaking, in the case of one road project and b) contracting out the building of a road to private contractors in another. Here the aim was to encourage small business development along the roads. Collaboration to construct roads has increased joint resource utilisation and mutual support and accountability. As one district official said:

In Kyenjojo we have tea-growing companies. Often we have asked these companies to work on the roads that traverse their farms to the neighbouring villages. We sometimes write to them or some of our politicians go physically to such companies, to request for assistance. For us as a district, we can offer a tractor/caterpillar/grader, our road engineer supervises the construction, while tea companies contribute fuel for running these machines and participate in monitoring the construction, so that the road comes out to a level that serves their interests. Roads have encouraged growth of businesses in 
the villages like food-selling points, and it is nowadays easy to transport produce to weekly or town markets. (District official 1)

Discussion with tea company owners indicated that their collaboration on infrastructure development reflected their desire to promote commercial farming, ease access to services and create more employment opportunities in the district. The attraction of network governance is largely due to the mutual benefit obtained. While the LG improves the roads to discharge its service delivery responsibilities, the tea companies want to be able to move their tea from the plantations to the factories more easily. As a staff member of the Mabale tea factory noted:

When we partner up with government to open up roads that link the factory to different villages, in a way we ease access to out-growers. As you know we are a cooperative and our vehicles traverse all these areas on a daily basis to collect tea leaves to deliver to the factory. It is important to work with government on the road network in a way that supports us, but we also support out-growers to sell their produce. These out-growers also support a number of workers and families. (Mabale company official)

These findings indicate that LGs initiate infrastructure collaboration with local commercial companies based on clear responsibilities as well as some incentives for local businesses and anticipated local economic benefits. In this case the LG and local companies agreed on the road standards, and the companies also monitored construction, providing immediate accountability. The road is used by the commercial companies to transport their produce to factories and markets, but it also serves local communities, such as out-growers transporting their produce to factories, and generally makes the rural areas more accessible and develops local businesses.

It was also observed that most interactions which yield such collaborations are brokered at the local level. It is when individual LG workers and tea company officials meet - in informal arenas like the Rotary Fellowship, Church, Lions Club or other social areas - that these contacts are initiated, and later formalised to comply with regulation and procedures.

Evidently, local politicians and technical engineers at LGs play a key role in successfully implementing road construction. However, the success of infrastructure development as a strategy seems to depend on a number of factors, including the social responsibility policies of companies and the incentives for individual companies. As a district official said:

We always go to these companies to ask them to make a contribution; sometimes we succeed and sometimes we don't. Sometimes maybe their businesses are not doing well or they may not have budgeted for such contribution. However, companies have a social responsibility budget and it is where such contribution on roads is often drawn from. (District official 1)

Companies have corporate social responsibility policies and budgets to promote their public image and maintain their customer base. As one officer noted, "We know that consumers buy from those companies that identify with them. It is one way of giving back to the consumers of our tea" 
(MTFO2). Therefore construction of a road helps companies to attract more consumers and maintain their market share. This was also confirmed with discussion with shopkeepers:

Mabale tea is consumed more by people in this town because it is good-quality tea. People also like the company because supply is reliable and it is a 'people's factory'. It is not run by individuals but by the farmers themselves. Also the company has done a lot in the district. For instance I have seen them support school competitions and sports days. (Shopkeeper 1)

These views indicate that people are willing to be involved. The primary interest in the network is to satisfy individual interests, e.g. for the tea company to ease movement of goods and please clients, and for the LG to be seen to be meeting its responsibilities, with LED following as a consequence. This points to the need for equitable cost-sharing to reflect the advantages gained by each actor in the network, as each will act to maximise their own interest.

Another factor for successful collaboration on infrastructure development has been the ability of politicians to convince companies to provide support and involve them in the LG planning process:

Usually the will for companies to make a contribution is there. My thinking is that we need to involve them in developing the district plans. This will enable them to include some of our expectations in their plans and then thereafter we can go to them to ask for a contribution. But also it depends on who is asking for support, some local politicians are not good at convincing companies and some are not trustworthy. But if we take up the issue of working with companies very seriously we can easily get money from them. (District official 1)

Private companies are seen as willing actors in network governance, who can easily supplement government budgets and efforts in transforming localities. Both formal and informal ties seem to be useful in initiating collaborative governance strategies. However, work with tea companies in Kyenjojo District seem to be ad hoc rather than pre-planned, and depends on trust and the resource mobilisation skills of LG officials. There is no systematic localised process to work with private companies to undertake development activities. However, it is worth noting that both elected and appointed officials in the district try to ensure goal congruence, and encourage business entities to be involved in oversight to a limited extent. However, coordination is fragmented and accountability is largely managerial, directed towards the LG and the contributing business owners rather than to the public. There may be a need for better leadership to improve the direction of the overall efforts of the network.

\section{Taxation}

Another strategy used by Kyenjojo is open or unregulated competitions where private companies are allowed to do business and government taxes them. Kyenjojo LG levies taxes on business entities such as hotels, shops and markets, and charges withholding taxes to contractors. Taxes are based on the size and nature of the business, and are usually in the form of licences. 
As one district official said:

We have small and big hotels like that of $\mathrm{Mr}$ Andrew; these are registered operators and they pay taxes by us giving them licences to operate. Some shops like supermarkets and others like abattoirs also acquire licences. However, we have a challenge of small businesses both in towns and in villages where owners do not want to register, they operate illegally and it becomes difficult to tax them. Even then, some operate like for a week and stop operations or they shift to new locations. The death rate of businesses here is too high. Those in rural areas are even worse, they operate in one's home where you cannot tell whether it is a shop or not. In such cases, people do not open their shops every day or sometimes open after work. (District official 2).

While formal businesses like hotels and supermarkets readily pay for licences to operate, thereby boosting LG income, the shops, kiosks and roadside stalls which are in the majority are likely to operate illegally and are therefore difficult to tax. In rural areas it is even harder to collect taxes because such businesses operate in people's compounds and homes. Licences are also an uncertain funding stream, as many businesses close after a few years or months, or shift location to new areas. Another government official said:

Yes, businesses die out, but licences are still the only reliable source of local government finances. The majority of the private operators know that it is illegal to start a business without paying for a licence or a receipt of any kind. Even those who just bring their produce to the market once in a while, they have to pay market dues. (District official 3)

There is no doubt that taxing local businesses contributes to LG revenues, though the tax base is said to be low. Taxing an unwilling population is also difficult, which can make the cost of collecting taxes exceed the taxes collected. Businesses devise different strategies to dodge paying taxes, including bribing local officials:

Sometimes the owners of retail shops just keep dodging taxes. When we send our boys there to go and collect taxes, they come back empty-handed. Sometimes if a retail shop was supposed to pay 30,000/= the boys will be given 1,000/= and told to collect next time. You find that the cost of collecting taxes from these shops is high compared to what we get. (District official 2)

Discussions with local businesses indicate that some dodge paying taxes because they do not relate taxation to service delivery: their capital is limited and they consider government does not give them any financial or technical support. As noted by a shopkeeper:

Government is just bent to tax businesses rather than supporting businesses to grow. I pay for everything: I pay rent, and utilities and garbage collection. So why does government take our taxes? I'm telling you if you are just starting and you begin by paying taxes you will just collapse. Taxes are very expensive. (Shopkeeper 5)

Discussion with district officials confirmed the view that people do not relate taxation to service delivery or appreciate what government is doing to create an enabling environment. 
As one of the officers noted:

People do not link everything government has done to business. For instance government has tarmacked the roads, extended electricity, extended mobile phone transmission gadgets to remote areas. Nowadays producers, wholesalers or even retailers just make mobile transactions. Government uses taxes to do these major investments. You ask them, if government did not do these investments, would they do them by themselves? (District official 5)

The interviews above suggest that taxpayers are always interested in the instrumental value of the taxes they pay: ie the direct benefit in terms of services. LED has to be understood in a wide context as involving not only local but also central government investments, because in Uganda funding to LGs from central government is subject to conditions and there is minimal funding for capital investment. Thus many local services important to businesses are provided by central government agencies.

Furthermore, tax collection is difficult in agricultural businesses -in this case tea companies - because of a political decision that agricultural produce need not be taxed. As one respondent said:

Another big issue we have in this district is that of tea plantations. As a district we had to think of how to increase our tax base and we made an ordinance here that these tea companies have to pay taxes. It was approved by council and by the Ministry of Local Government, but you know what, the President of Uganda pronounced that taxes should not be levied on agricultural produce. Now we have the ordinance but we cannot use it to get local revenues from these tea companies. They are protected; you cannot get money from them through taxation. (District official 2)

Discussion with Mabale tea company officials indicated that companies do pay numerous indirect taxes but these mainly go to central government, apart from the local income tax paid by workers, which is retained by local government. As noted by a Mabale company official:

Local governments access our payroll: each worker pays local income tax from their salary and we transfer this to Kyenjojo District. (Mabale company official)

Another issue is the national legal framework for taxation, which allows the Uganda Revenue Authority (URA) to tax businesses within the jurisdiction of LGs. As one official said:

The issue we have in taxation is that of the URA. For instance we give contracts to companies to undertake certain projects. We tax them $6 \%$ withholding tax, but we have to remit that to the URA as clean money. This money should be left at the districts. By taking withholding money it is as if URA is taxing districts. URA takes avenues of taxes that are easy to collect and they give LGs responsibility to collect those that are hard to get from people. It is costly to chase shopkeepers with law enforcers for 30,000/= only. In fact for us in $L G$, we think if URA is a good tax collector, it should collect all and then give us the money. (District official 1)

URA is thus seen as a hindrance to local revenue generation, not only in Kyenjojo District but in all LGs. This conflict is also likely to be one cause of laxity in collecting taxes at LG level. But, more 
fundamentally, most of the 'easy to collect' and 'most voluminous' taxes are collected by the centre, not by LGs.

This study did find that a taxation strategy increased LG resources. However, the strategy is hampered in many ways: unwillingness of business owners to pay taxes; political decisions which counteract LG ordinances or by-laws; failure to register micro enterprises; high failure rates among small businesses; and the diverting of some taxes paid by local businesses to central government.

\section{Contracting out}

Kyenjojo District contracts out service delivery to private companies and individuals largely according to public procurement laws and guidelines. Most LGs in Uganda employ trained procurement officers who manage all procurements. Contracting takes several forms in Kyenjojo District. The first is where services are tendered out, private companies provide the service to the population, and government pays for the service delivery. As noted by an LG official:

I will give you an example of road construction. We use public procurement guidelines to tender out roads, private companies compete, they undertake the construction and LG pays them for the work done. (District official 3)

Under such arrangements LGs pay for the services rendered and the private sector sees it as an opportunity to earn money through contracting:

Government is one of the entities that undertake more investments like construction of roads, schools, hospitals compared to individual businesses. To me it is one source of big business; at least if I take two tenders from government on an annual basis then I can sustain my company. (Road contractor 2)

Thus, through contracting, local business companies earn income and sustain their businesses. Government officials also confirmed that contracting out is strongly promoted by government policy, since LGs have limited staffing and so private service providers are necessary. As noted by an LG official:

In Kyenjojo here we offer contracts to private service providers almost in all fields, eg garbage collection, beautification of the towns, road construction, markets, as well as taxi and bus parks. This is because in the past years there has been this thinking that government does not know how to do business and therefore we had to give everything to the private service provider and remain with the role of monitoring. Again you could be knowing that LGs are not fully staffed, we operate at staffing levels of about 40-50\%; therefore service providers fill that capacity gap. (District official 4)

These two aspects - a wish to minimise direct government provision of services combined with limited staffing levels - have influenced LG contracting out practices. Contracting out both helps to bridge capacity gaps and enhances the monitoring role of government, according to one government official:

Our role in road construction is to supervise through the technical officers, especially the road engineers. We also work with communities to negotiate boundaries, settle 
conflicts and ask them to supervise contractors on a daily basis. We hold site meetings with communities to hear their issues through the community development officers. (District official 5)

The success of contracted out services relies on the participation of stakeholders and the ability of the LG to monitor and supervise and to ensure quality service delivery. This study found that it is technical departments which carry out supervision and manage the relationships between actors.

Contracting out also may take a second form, leasing, where the supervision input from the LG is less, because in this case the contractor is also responsible for supervision. In this case the LG earns money from the contractor, as one official explained:
Another example is that of markets and taxi and bus parks. We tender out these places all over the district. The contractor pays the contract sum and thereafter collects taxes from the users, and maintains the cleanliness of these places. Our role as $L G$ is to ensure that the contractor does not for instance mistreat market vendors and maintains acceptable levels of hygiene of the market. These are reliable sources of $L G$ funding because we just sign a contract and all we want is our payment of the agreed upon amount as the rest is handled by the contractor. (District official 1)

The leasing of markets or taxi ranks and bus parks is seen as a reliable source of LG income because the business owner assumes the commercial risks involved in operations, maintenance and management of these services while also paying rental fees to LGs. The role of the LG here is to enforce standards and safeguard consumer rights.

While leasing out assets like markets and taxi ranks is a good source of LG income, it is sometimes seen as curtailing business:

The challenge is that such avenues are few. We have few markets, taxi and bus parks in the district to tender out. In addition to that there is what we call business curtailing: the private companies know each other and they connive and agree to offer little contract value to the district despite the research we do before setting the reserve price. For instance the taxi and bus parks in this town can fetch like 100 million per year each, which is really little money. Sometimes we have reacted by undertaking the collection of taxes ourselves, but the challenge has been, our tax collectors will fail to even get a quarter of the taxes. They will tell you that people are difficult. (District official 3)

Business curtailing decreases income from this kind of contracting, and even efforts by LGs to collect taxes themselves do not seem to make much difference. It is also not clear that this form of contracting improves the local economy. Discussions with market vendors and taxi drivers indicate that contracting out markets and taxi ranks to individual contractors may relieve government of dayto-day management hassles, but the tax burden borne by market vendors and taxi drivers is transferred on to local consumers. 


\section{Discussion of findings}

LED in Kyenjojo District is implemented using three major network governance strategies which provide incentives for private actors to participate in developing their localities. The strategies are infrastructure development, taxation and contracting out. Although Kyenjojo District does not have a LED policy, it broadly follows national policy, and as such the three network governance arrangements do influence financial autonomy, functional capacity and innovative capacity of the district.

\section{LG financial autonomy}

Infrastructure development, taxation of hotels and supermarkets, and contracting out the management of markets, taxi ranks and bus parks are strategies likely to earn income for LGs to invest in LED. Although infrastructure development partnerships with tea plantations do not bring in cash, they bring resources in kind which supplement LG resources in complex situations. This finding is consistent with Parag et al. (2013) and Giest and Howlett (2013), who claim that network governance increases access to resources. However, there was no evidence in this study that network governance reduced the LG's transaction costs in transforming the local economy. This is because Kyenjojo's potential sources of income, especially taxation, were seen as difficult to access and unresponsive to network governance arrangements. The unwillingness to pay taxes, especially by small enterprises, was attributed to a lack of strong incentives, inadequate enforcement, and the high failure rate of small businesses.

Even in a horizontal network arrangement where, for instance, the LG is collaborating with private actors to develop local economies, intergovernmental relationships still seem to be influential, especially through regulations and political pronouncements. In organising contracting out, Kyenjojo LG uses national procurement policies and regulations. In setting taxation, some taxes which the LG would like to keep must by law be passed to central government, while other sources of income, for instance taxation of agricultural produce, are prohibited by presidential pronouncements even though Kyenjojo is an agriculture-based economy. These factors mean that the LG is hampered both in increasing income from local avenues and in deciding how to use this income.

\section{LG functional capacity}

Analysis of the three network governance arrangements employed by Kyenjojo District show that LG technical staff and politicians play a key role in initiating, supervising and monitoring network activities. In infrastructure development arrangements, district engineers and community development officers provide technical oversight. In contracting out, procurement officers use procurement guidelines to initiate and manage contracts. Although government staff would traditionally be the implementers, roles seem to have changed and there is no evidence that these network governance 
arrangements have led to the development of specialised skills in, for instance, regulation or law enforcement. Capacity gaps are evident in understanding the private sector and how it works. Kyenjojo LG has no clear plan on how to work with private actors; private actors are engaged on ad hoc basis; and there are no innovative strategies for raising taxes from small-scale enterprises or even curtailing business collusion. Thus even with network governance there is a growing sense among LGs that working with the private sector is hard. Just as Provan and Kenis (2008) and Giest and Howlett (2013) argue, willingness to cooperate depends on the incentives available, and these are lacking in LGs.

Some researchers have observed that network governance leads to loss of oversight by the state over public goods and services (Carlsson and Sandstrom 2008), when services traditionally provided by the public sector, such as roads, switch to being offered by the private sector. However, this study found the functional capacity of Kyenjojo LG to maintain regular oversight, coordination and steering was in place, although some respondents suggested that it had been undermined.

\section{LGs' capacity for innovation}

The 2013 Commonwealth Local Governance Conference emphasised that LGs can steer development of their own localities if they seize local opportunities and encourage community participation. The Kyenjojo case indicates that LGs do have the potential to imagine and access alternative sources of funding and options for development. Two examples are the work with local tea companies to co-fund and implement infrastructure development, and the creation of an ordinance to levy taxes on tea companies as a source of income. These initiatives demonstrate how innovative LG practices can support LED, as long as central government does not come to view LG as something essentially different from a scaled-down version of national governance (Grydehøj 2013). Therefore, strong networks at the local level do have the potential to promote LG innovation.

It is also apparent that the innovation capacity of LGs can arise in both informal and formal structures. Informal social networks are based on personal relationships between actors in the LG policy network. These can be later formalised to enable implementation of agreed actions or innovations, because shared knowledge, information and expertise generates higher levels of trust (Voets and de Rynck 2008). Thus relationships arising in informal networks lead to projects such as the construction of roads within tea plantations under a unique cost-sharing arrangement: the district provides the political support and mobilisation, and the tea companies provide the fuel and allowances for the drivers. Infrastructure is improved in a new, non-traditional way, and civil servants are encouraged to think 'outside the box'. 


\section{Conclusions}

Although legal frameworks seem to provide LGs with financial autonomy, there is a paradox: a disconnect between the discretion of LGs to collect revenue and allocate budgets, and the fact that most funds are remitted to the centre, not kept locally - hence undermining localism. The problem is compounded by the political need for central government to exercise oversight over LGs. Though network governance does provide opportunities to increase LGs' financial autonomy, intergovernmental relationships, limited involvement of private actors and national political decisions seem to constrain the networking potential.

One of the promised benefits of networked government is that it will boost the functional capacity of LGs. The United Nations Development Programme in 2007 noted five key functional capacities for LGs: to engage with stakeholders; to assess a situation and define a vision and mandate; to formulate policies and strategies; to budget, manage and implement; and to monitor and evaluate. Public/private sector synergies and organisational learning are not enough to enhance these capacities; deliberate and systematic approaches and incentive systems are also needed.

Capacity for innovation is one of the key stimulants to LED. However, the challenge is to create and sustain this capacity in LGs within the current framework. This paper has found that innovation seems to be constrained by intergovernmental relations, especially between the centre and LGs. The freedom to act independently and to determine local priorities should be widened and strengthened. The mandate and jurisdiction of LGs need to be reviewed, since it appears that innovation is not easily promoted in a constricted space.

\section{References}

Ateljevic, J., O’Rourke, T. and Poljasevic, B.Z. (2013) Local economic development in Bosnia and Herzegovina: Role of local development agencies. Balkan and Near Eastern Studies. 15 (3), 280-305. doi: http://dx.doi.org/10.1080/19448953.2013.789319

Awortwi, N. (2003) Getting the fundamentals wrong: Governance of multiple modalities of basic service delivery in three Ghanaian cities. The Hague, the Netherlands: Shaker Publishers.

Bar-Nir, D. and Gal, J. (2010) Who has the power? The role of NPOs in local authorities. VOLUNTAS: International Journal of Voluntary and Non-profit Organizations, 22 (1), 1-25. doi: http://dx.doi.org/10.1007/s11266-010-9144-6

Bitarabeho, J. (2008) The experience of Uganda local governments role as a partner in the decentralisation process to strengthen local development. A paper presented to a conference on: Access to Development Funding for Local Governments in Africa, September 15-17, Emperors Palace Hotel, Johannesburg.

Bodolica, V. and Spraggon, M. (2009) Merger and acquisition transactions and executive compensation: A review of the empirical evidence. Journal of the Academy of Management and Annals, 3 (1) 109-181. doi: http://dx.doi.org/10.1080/19416520903047210

Bogason, P. and Musso, J.A. (2006) The democratic prospects of network governance. American Review of Public Administration, 36 (1), 3-18. doi: http://dx.doi.org/10.1177/0275074005282581

Carlsson, L. and Sandstrom, A. (2008) Network governance of the commons. International Journal of the Commons, 2 (1), 33-54. doi: http://dx.doi.org/10.18352/ijc.20 
Choong, C. and Lam, S. (2010) The determinants of foreign direct investment in Malaysia: A revisit. Journal of Global Economic Review, 39 (2), 175-195. doi: http://dx.doi.org/10.1080/1226508X.2010.483837

Commonwealth Local Government Forum (CLGF) (2013) Developmental local government: Putting local government at the heart of development. Commonwealth Local Government Conference Report. 14-17 May 2013, Munyonyo Commonwealth Conference Centre, Kampala, Uganda. Available at: http://www.clgf.org.uk/userfiles/1/file/3576\%20kampala\%20conference\%202013.pdf [Accessed 6 November 2015].

Cristofoli, D., Markovic, J. and Meneguzzo, M. (2014) Governance, management and performance in public networks: How to be successful in shared-governance networks. Journal of Management \& Governance, 18 (1), 77-93. doi: http://dx.doi.org/10.1007/s10997-012-9237-2

de Vries, M.S. and Nemec, J. (2012) Global trends in public sector reforms. Brussels: Bruylant.

Giest, S. and Howlett, M. (2013) Understanding the pre-conditions of commons governance: The role of network management. Environmental Science and Policy, 36, 37-47. doi: http://dx.doi.org/10.1016/j.envsci.2013.07.010

Grant, B. and Dollery, B. (2012) Autonomy versus oversight in local government reform: The implications of 'home rule' for Australian local government. Australian Journal of Political Science, 47 (3), 399-412. doi: http://dx.doi.org/10.1080/10361146.2012.704003

Green, G.P. (2003) Civic involvement, organisational ties and local economic development. Community Development Society Journal, 34 (1), 1-17. doi: http://dx.doi.org/10.1080/15575330309490100

Grydehøj, A. (2013) Challenges to local government innovation: Legal and institutional impediments to the exercise of innovative economic development policy by subnational jurisdictions. European Journal of Spatial Development. Refereed article No.50, April 2013, Available at: http://www.nordregio.se/Global/EJSD/Refereed articles/refereed50.pdf

Hansen, T. and Klausen, J.E. (2002) Between the welfare state and local government autonomy. Journal of Local Government Studies, 28 (4), 47-66. doi: http://dx.doi.org/10.1080/714004167

Huntington, H. and Wibbels, E. (2014) The geography of governance in Africa: New tools from satellites, surveys and mapping. Journal of Regional and Federal Studies, 24 (5), 625-645. doi: http://dx.doi.org/10.1080/13597566.2014.971774

International Labour Organization. (2006) A local economic development manual for China. Geneva: ILO.

Imhanlahimi, J.E. and Ikeanyibe, M.O. (2009) Local government autonomy and development of localities in Nigeria: Issues, problems and suggestions. Global Journal of Social Sciences, 8 (2). Available at: http://www.ajol.info/index.php/gjss/article/view/51575

Jones, G. and Stewart, J. (2012) Local government: the past, the present and the future. Public Policy and Administration, 27 (4), 346-367. doi: http://dx.doi.org/10.1177/0952076712439979.

Kagame, P. (2013) Keynote speech, Transformational local government. In: Developmental local government: Putting local government at the heart of development. 2013 Commonwealth Local Government Conference Report. 14-17 May 2013, Munyonyo Commonwealth Conference Centre, Kampala, Uganda. Available at: www.clgf.org.uk/userfiles/1/file/3576\%20kampala\%20conference\%202013.pdf [Accessed 6 November 2015].

Karyeija, G. and Kyohairwe, S. (2012) Organizational puzzles of agencification: A Kampala city council authority case. Journal of African and Asian Local Government Studies, 1 (4), 106-115.

Khan, J. (2013) What role for network governance in urban low carbon transitions? Journal of Cleaner Production, 50 (1) 133-139. doi: http://dx.doi.org/10.1016/j.jclepro.2012.11.045

Kiwanuka, M. (2014) National welfare or local welfare? The fiscal decentralization paradox in Uganda. The Journal of African \& Asian Local Government Studies, 2 (3), 92-106.

Koppenjan, J. and Klijn, E.H. (2004) Managing uncertainties in networks: A network approach to problem solving and decision making. London: Routledge. 
Lewis, J.I. (2014) When decentralisation leads to recentralisation: Sub-national state transformation in Uganda. Journal of Regional and Federal Studies, 24 (5), 571-588. doi: http://dx.doi.org/10.1080/13597566.2014.971771

Ministry of Finance, Planning and Economic Development. (2015) Budget at a glance for FY2015/16. Kampala. Available at: http//:www.finance/budget.go.ug [Accessed 5 November 2015].

MoLG. (2013) Local development outlook - Uganda: Strengthening local development initiatives for enhanced decentralisation and effective service delivery. Kampala, Uganda: Government of Uganda.

MoLG. (2014) Local economic development policy. Kampala, Uganda: Government of Uganda.

Mubangizi, B.C., Nhlabathi, Z.F. and Namara, R. (2013) Network governance for service delivery: Lessons from South Africa and Uganda. Journal of Public Administration. Special Issue: Governance and Leadership, 48 (4.1), 774-795.

Nabukeera, M., Boerhannoeddin, A., Ariffin, R. and Bwengye, M. (2015) Recentralization of Kampala city administration in Uganda: Implications for top and bottom accountability. SAGE Open, 5 (3).

Palermo, S. (2015) Local autonomies and economic development in Italy's incomplete transition. Journal of Modern Italian Studies, 20 (2), 245-251. doi: http://dx.doi.org/10.1080/1354571X.2015.997496

Parag, Y., Hamilton, J., White, V. and Hogan, B. (2013) Network approach for local and community governance of energy: The case of Oxfordshire. Energy Policy, 62 (2013) 1064-1077. doi: http://dx.doi.org/10.1016/j.enpol.2013.06.027

Park, H.J.A and Park, M.J. (2009) Types of network governance and network performance: Community development project care. International Review of Public Administration, 13 (1), 91-105. doi: http://dx.doi.org/10.1080/12294659.2009.10805142

Provan, K.G. and Kenis, P. (2008) Modes of network governance: structure, management, and effectiveness. Journal of Public Administration Research and Theory, 18 (2), 229-252. doi: http://dx.doi.org/10.1093/jopart/mum015

Read, D.M.Y and Parton, K.A. (2009) Economic deregulation and trade liberalisation in Kenya, Tanzania and Uganda: Growth and poverty. Journal of Economic Issues, 43 (3), 567-586. doi: http://dx.doi.org/10.2753/JEI0021-3624430301

Redman, T., Snape, E., Wass, J. and Hamilton, P. (2007) Evaluating the human resource shared services model: Evidence from the NHS. The International Journal of Human Resource Management, 18 (8), 14861506. doi: http://dx.doi.org/10.1080/09585190701502612

Rees, F.C. and Hossain, F. (2010) Perspectives on decentralisation and local governance in developing and transitional countries. International Journal of Public Administration, 33 (12 \& 13), 581-587. doi: http://dx.doi.org/10.1080/01900692.2010.514459

Reese, L.A. (2006) Do we really need another typology? Clusters of local economic development strategies. Economic Development Quarterly, 20 (4), 368-376. doi: http://dx.doi.org/10.1177/0891242406291630

Rogerson, C.M. (2010) Local economic development in South Africa: Strategic challenges. Journal of Development Southern Africa, 27 (4), 481-495. doi: http://dx.doi.org/10.1080/0376835X.2010.508580

Rogerson, C.M. and Rogerson, J.M. (2010) Local economic development in Africa: Global context and research directions. Journal of Development Southern Africa, 27 (4), 465-480. doi: http://dx.doi.org/10.1080/0376835X.2010.508577

Ruecker, A. and Trah, G. (2007) Local and regional economic development: Towards a common framework for GTZ's LRED interventions in South Africa. Eschborn: GTZ (German Technical Cooperation).

Swianiewicz, P. (2014) An empirical typology of local government systems in Eastern Europe. Journal of Local Government Studies, 40 (2), 292-311. doi: http://dx.doi.org/10.1080/03003930.2013.807807

Trah, G. (2004) Business development services and local economic development. Programme description of GTZ Local Economic Development \& Business Development Services Programme. Pretoria: GTZ South Africa Office.

Tshikwatamba, N.E. (2012) Public sector human resource developments in developmental states in Africa. In: de Vries, M.S. and Nemec, J. Global trends in public sector reforms. Brussels: Bruylant. 
Turnbull, S. (2007) Analysing network governance of public assets. Corporate Governance: An International Review, 15 (6), 1079-1089. doi: http://dx.doi.org/10.1111/j.1467-8683.2007.00632.x

UNDP (2007) Supporting capacities for integrated local development. Practice Note. Available at: http://www.undp.org/content/dam/aplaws/publication/en/publications/poverty-reduction/povertywebsite/supporting-capacities-for-integrated-local-development/Supporting-Capacities-IntegratedLocalDev-PracticeNote.pdf

Voets, J. and de Rynck, P. (2008) Exploring the innovative capacity of intergovernmental network managers: The art of boundary scanning and boundary spanning. In: Bekkers, V., Edelenbos, J. and Steijn, B. (eds) Innovation in the public sector: Linking capacity and leadership. Houndsmills: Palgrave McMillan, pp. 155-175.

Wilikilagi, V. (2009) What is network governance and its implications for public policy formulation? Social Science Research Network. Available at: http://ssrn.com/abstract=1494757 or doi: http://dx.doi.org/10.2139/ssrn.1494757 